\title{
Heavy metal and metalloid contamination in the sediments of the Spekboom River, South Africa
}

\author{
Abraham Addo-Bediako $^{1}$ (D) Sophy Nukeri ${ }^{1} \cdot$ Millicent Kekana $^{1}$
}

Received: 1 April 2021 / Accepted: 24 June 2021 / Published online: 4 July 2021

(c) The Author(s) 2021

\begin{abstract}
The impact of anthropogenic activities such as mining, agriculture and urbanization is causing heavy metal contamination in many freshwater ecosystems. The concentrations of eight elements ( $\mathrm{As}, \mathrm{Cr}, \mathrm{Cu}, \mathrm{Fe}, \mathrm{Mn}, \mathrm{Ni}, \mathrm{Pb}$ and $\mathrm{Zn}$ ) in the Spekboom River, South Africa, were studied using enrichment factor $(\mathrm{EF})$ and geo-accumulation index $\left(\mathrm{I}_{\text {geo }}\right)$ to assess the extent of pollution in the river. Sediment samples were collected and analyzed using sequential inductively coupled plasma—optical emission spectrometry. The results showed deterioration of the sediment quality with high concentration of $\mathrm{Cr}$ and $\mathrm{Ni}$ at all the sites, this is a reflection of contamination from the various anthropogenic activities in the area. The current levels of $\mathrm{Cr}$ and $\mathrm{Ni}$ could be detrimental to the river and may pose a serious threat to the aquatic organisms and humans, as the sediment could act as a secondary source of metal pollution in the water. It is therefore recommended that urgent action should be taken to control effluents from anthropogenic activities to the river in order to prevent further pollution.
\end{abstract}

Keywords Heavy metals $\cdot$ Pollution $\cdot$ River sediments $\cdot$ Enrichment factor $\cdot$ Geo-accumulation

\section{Introduction}

Many aquatic ecosystems are polluted globally to an extent that they are no longer fit for their intended use. Pollution of freshwater ecosystems by heavy metals is a global issue because of their lethal effects, persistence, abundance, and toxicity in the aquatic environment (Benzer 2017; Zhang et al. 2017; Addo-Bediako 2020). They are among the common widespread pollutants originating from anthropogenic activities, such as mining, agriculture and industries (Jan et al. 2015). High concentrations of heavy metals in the aquatic environment can be detrimental to the aquatic biota. One of the biggest problems is the potential for bioaccumulation and biomagnification in the bodies of aquatic organisms at concentrations higher than that of their environment. As a result, the concentrations of most metals are often used to provide basic information for the decisions of environmental health risks (Gao and Chen 2012).

Sediments can act as a sink for heavy metals and other detrimental substances and therefore play an important role

Abraham Addo-Bediako

abe.addo-bediako@ul.ac.za

1 Department of Biodiversity, University of Limpopo, Private Bag X1106, Sovenga 0727, South Africa in maintaining the normal aquatic environments (Yang et al. 2016). However, sediments may pose a risk of secondary water pollution under sediment disturbance and/or changes in the geo-chemistry of sediments and may cause a decline in water quality. High concentrations of heavy metals in the sediment can also lead to bioaccumulation in living organisms through direct absorption or through the food chain (Addo-Bediako et al. 2014). Sediments, in addition to biological monitoring, can therefore be used to provide historical records of water quality of rivers (Arnason and Fletcher 2003).

In South Africa, water quality concerns include sedimentation, salinization, eutrophication, microbial pollution, and acidification because of the unregulated mining activities (Du Plessis 2017). The Spekboom River serves as a source of water to several communities in the catchment. Despite the importance of this river to the communities, little is known about the health status of this river since minimal research has been done. The river is adversely affected by contaminated water due to the constant increase in agricultural, mining and industrial activities in the catchment areas (Van Veelen and Dhemba 2011). The effluents from such activities contain complex mixtures of chemicals, many of which may have deleterious effects on the aquatic system (Hook et al. 2016). In addition, the uncontrolled release of 
treated and raw sewage in the river catchment has been identified as a major concern. This has raised concern over the potential long-term impact of water pollution on the health of the communities within the river catchment, especially those still reliant on untreated water from the river.

It is therefore important to monitor the Spekboom River to ensure that the levels of ecological integrity are maintained and to be aware of the potential risks that polluted water might have on the aquatic biota and the human communities in the catchment. The objectives of the study were to assess metalloid, arsenic (As) and heavy metals, chromium $(\mathrm{Cr})$, copper $(\mathrm{Cu})$, iron $(\mathrm{Fe})$, manganese $(\mathrm{Mn})$, nickel $(\mathrm{Ni})$, lead $(\mathrm{Pb})$ and zinc $(\mathrm{Zn})$ pollution and to determine potential sources of pollution in the sediments of the Spekboom River. For the purpose of this study, all the chemical elements would be referred to as heavy metals.

\section{Materials and methods}

The Spekboom River flows adjacent to Burgersfort Town in the Limpopo Province of South Africa. It originates in the mountains near Lydenburg and flows in a northerly direction to join the Steelpoort River, northwest of Burgersfort. From here, the Steelpoort River flows in a north-easterly direction and converges with the Olifants River in the Drakensberg near Kromellenboog. The area surrounding this river is characterized by human settlements, agricultural and mining activities (Van Veelen and Dhemba 2011). There is overgrazing and cultivation of dryland along the Spekboom River (Van Veelen and Dhemba 2011) which leads to erosion and consequently high silt levels in the river, resulting in degradation of in-stream habitats and loss of aquatic biota. The basin is characterized by long summer but short winter, spring and autumn. The annual average maximum temperature is $24^{\circ} \mathrm{C}$, and the annual average minimum temperature is $11^{\circ} \mathrm{C}$. The average annual rainfall is about $730 \mathrm{~mm}$.

\section{Sediment sampling}

Surface sediments were collected from four different sections of the river representing the major activities in the catchment, agriculture, wastewater treatment plant (WWTP), human settlements and urban-mining areas (Fig. 1). Surface sediment samples were collected at a depth of $0-10 \mathrm{~cm}$ using a spatula. At each site, five sub-samples were mixed together, forming a composite sample (Bervoets and Blust 2003).

At each site, five sub-samples were mixed together, forming a composite sample (Bervoets and Blust (2003). The samples were placed in $10 \%$ nitric acid pre-treated polyethylene ziplock bags, transported to the laboratory and were frozen $\left(-20^{\circ} \mathrm{C}\right)$ prior to chemical analysis (UNEP 2005). Sediment samples were analyzed for elements at an accredited (ISO 17,025) chemical laboratory (WATERLAB (PTY) LTD in Pretoria, South Africa. The samples were put in acid-washed polypropylene pre-weighed vials and dried at $60{ }^{\circ} \mathrm{C}$ for $24 \mathrm{~h}$. The samples were then sieved through a 2-mm nylon sieve to remove any stones and coarse debris. Then, $0.1 \mathrm{~g}$ of each sediment sample was digested with $8 \mathrm{~mL}$ of $68 \%$ nitric acid (HNO3) and $3 \mathrm{~mL}$ of $40 \%$ hydrochloric acid $(\mathrm{HCl})$. It was then filtered through a membrane filter and the concentrations of $\mathrm{As}, \mathrm{Cr}, \mathrm{Cu}, \mathrm{Fe}, \mathrm{Mn}, \mathrm{Ni}, \mathrm{Pb}$ and $\mathrm{Zn}$ were analyzed using inductively coupled plasma-optical emission spectrometry (ICP-OES) (Perkin Elmer, Optima 2100 DV). Concentrations of the metals in the sediments were calculated and expressed as $\mathrm{mg} / \mathrm{kg}$ dry weight. Analytical accuracy was determined using certified standards (De Bruyn Spectroscopic Solutions 500 MUL20-50STD2) and recoveries were within $10 \%$ of certified values. There are no established national sediment quality guidelines in South Africa, hence the results of heavy metals in sediments were compared with the Canadian Interim Sediment Quality Guidelines (ISQG) proposed by the Canadian Sediment Quality Guidelines for the Protection of Aquatic Life (CCME 2012).

\section{Statistical analysis}

The mean and standard deviation of the metals/metalloid were determined. Two-way analysis of variance (ANOVA) was done to determine differences for mean metal concentrations among sites and seasons. The occurrence of a linear correlation between analyzed variables was evaluated by Spearman's correlation coefficient (r). All statistical analyses were done using Statistica (Version 10).

Enrichment factor (EF) method was used to assess the presence and level of pollution in the sediment (Barbieri 2016; Hanif et al. 2016). EF is calculated as:

$\mathrm{EF}=\left[\mathrm{C}_{\mathrm{x}} /(\mathrm{Fe})\right] /\left[\left(\right.\right.$ Baseline $\left._{\mathrm{x}}\right) /($ Baseline $\left.\mathrm{Fe})\right]$

where $\mathrm{C}_{\mathrm{x}}$ is the metal concentration (Brady et al. 2014; Gao et al. 2014). The average shale values of metals by Turekian and Wedepohl (1961) was used as background values for heavy metals. The concentration of Fe was used as a reference value for the study. To account for natural heavy metal concentrations, $\mathrm{EF}$ is normalized to sediment using $\mathrm{Al}$ or Fe content. In this study, Fe was selected while determining 


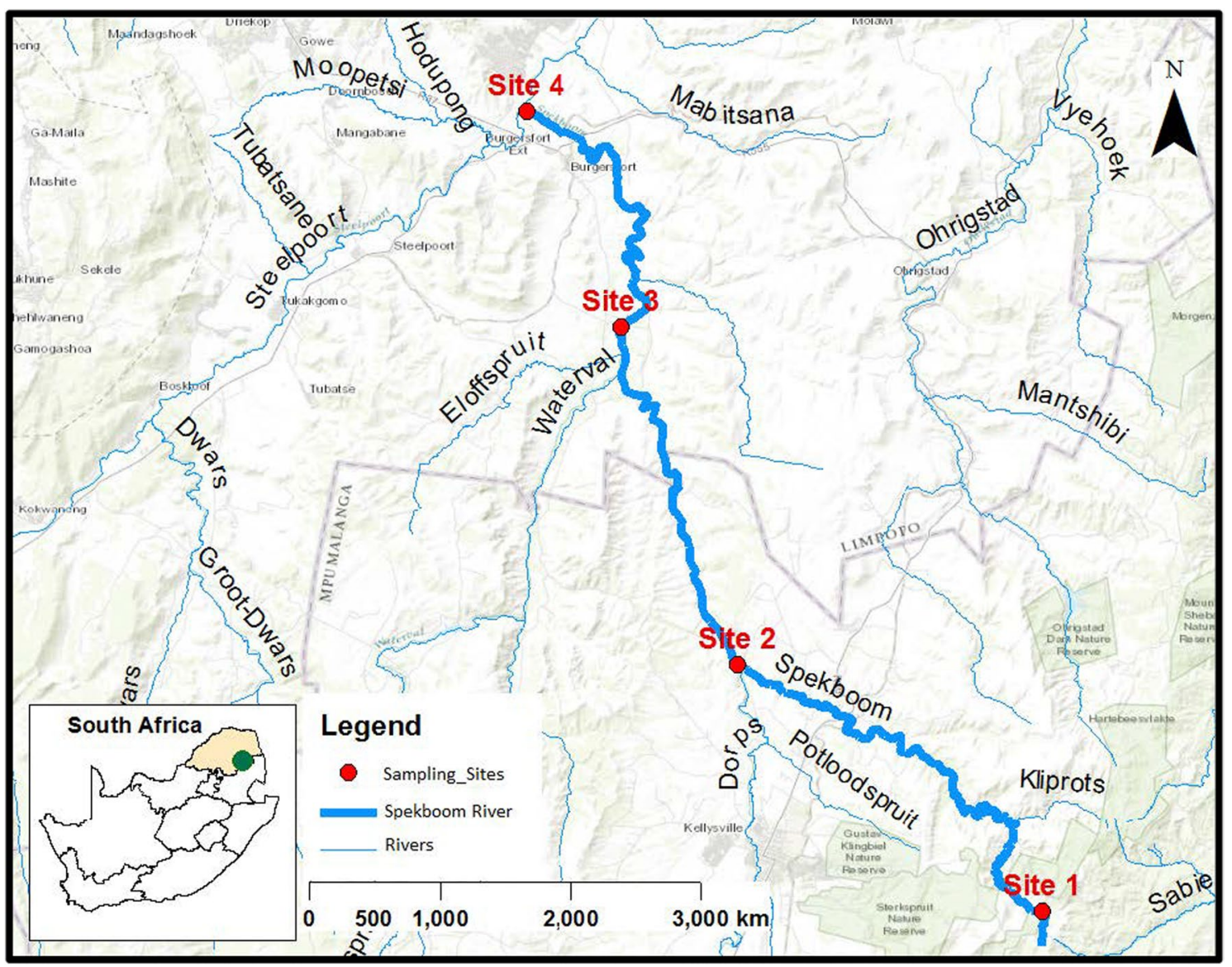

Fig. 1 Map showing the sampling sites along the Spekboom River, South Africa

EF values. Several authors have successfully used iron (Fe) to normalize heavy metal contaminants (Deely and Fergusson 1994; Bhuiyan et al. 2010). Values of EF were used to assess the pollution of bottom sediment samples into the following classes: $(\mathrm{EF}<2)$ deficiency to minimal enrichment; $(2<\mathrm{EF}<5)$ moderate enrichment; $(5<\mathrm{EF}<20)$ significant enrichment; $(20<\mathrm{EF}<40)$ very high enrichment; and $(\mathrm{EF}>40)$ extremely high enriched (Barbieri 2016).

Geo - accumulation index $\left(\mathrm{I}_{\text {geo }}\right)$

The index of geo-accumulation ( $\left.\mathrm{I}_{\text {geo }}\right)$ was used to measure the sediment contaminations. It considers both natural
Table 1 Mean heavy metal/ metalloid concentrations ( $\mathrm{mg} /$ $\mathrm{kg}$ ) of the Spekboom River sediment with the CCME reference average shale values

\begin{tabular}{|c|c|c|c|c|c|c|c|c|c|c|}
\hline \multirow[b]{2}{*}{ Metals } & \multicolumn{2}{|l|}{ Site 1} & \multicolumn{2}{|l|}{ Site 2} & \multicolumn{2}{|l|}{ Site 3} & \multicolumn{2}{|l|}{ Site 4} & \multirow[t]{2}{*}{ SQG } & \multirow{2}{*}{$\begin{array}{l}\text { Shale* } \\
\text { value }\end{array}$} \\
\hline & Mean & SD & Mean & SD & Mean & SD & Mean & SD & & \\
\hline As & 1.898 & 0.51 & 3.585 & 0.837 & 4.561 & 1.6714 & +2.204 & 1.248 & 5.9 & 13 \\
\hline $\mathrm{Cr}$ & 1168.5 & 359.7 & 819.75 & 217.35 & 873.5 & 265.81 & 1504.75 & 1808.9 & 37.3 & 90 \\
\hline $\mathrm{Cu}$ & 18.2 & 8.0 & 16.0 & 3.92 & 20.25 & 6.02 & 25.5 & 14.0 & 35.7 & 45 \\
\hline $\mathrm{Fe}$ & 48,678 & 5119 & 38,050 & 4236.5 & 37,589 & 3184.3 & 84,128 & 34,507 & - & 47,200 \\
\hline $\mathrm{Mn}$ & 1129 & 130.2 & 760.5 & 177.5 & 648.3 & 101.95 & 1080 & 265.5 & - & 850 \\
\hline $\mathrm{Ni}$ & 521.75 & 174.6 & 424.5 & 149.02 & 401.75 & 226.37 & 436.25 & 400.06 & - & 68 \\
\hline $\mathrm{Pb}$ & 4.76 & 1.65 & 5.26 & 2.66 & 7.26 & 3.45 & 4.54 & 0.78 & 35 & 20 \\
\hline $\mathrm{Zn}$ & 47.25 & 34.36 & 28.25 & 21.58 & 47.5 & 12.45 & 96.5 & 56.68 & 123 & 95 \\
\hline
\end{tabular}

*Turekian and Wedepohl (1961); SQG = Sediment Quality Guideline (CCME 2012 

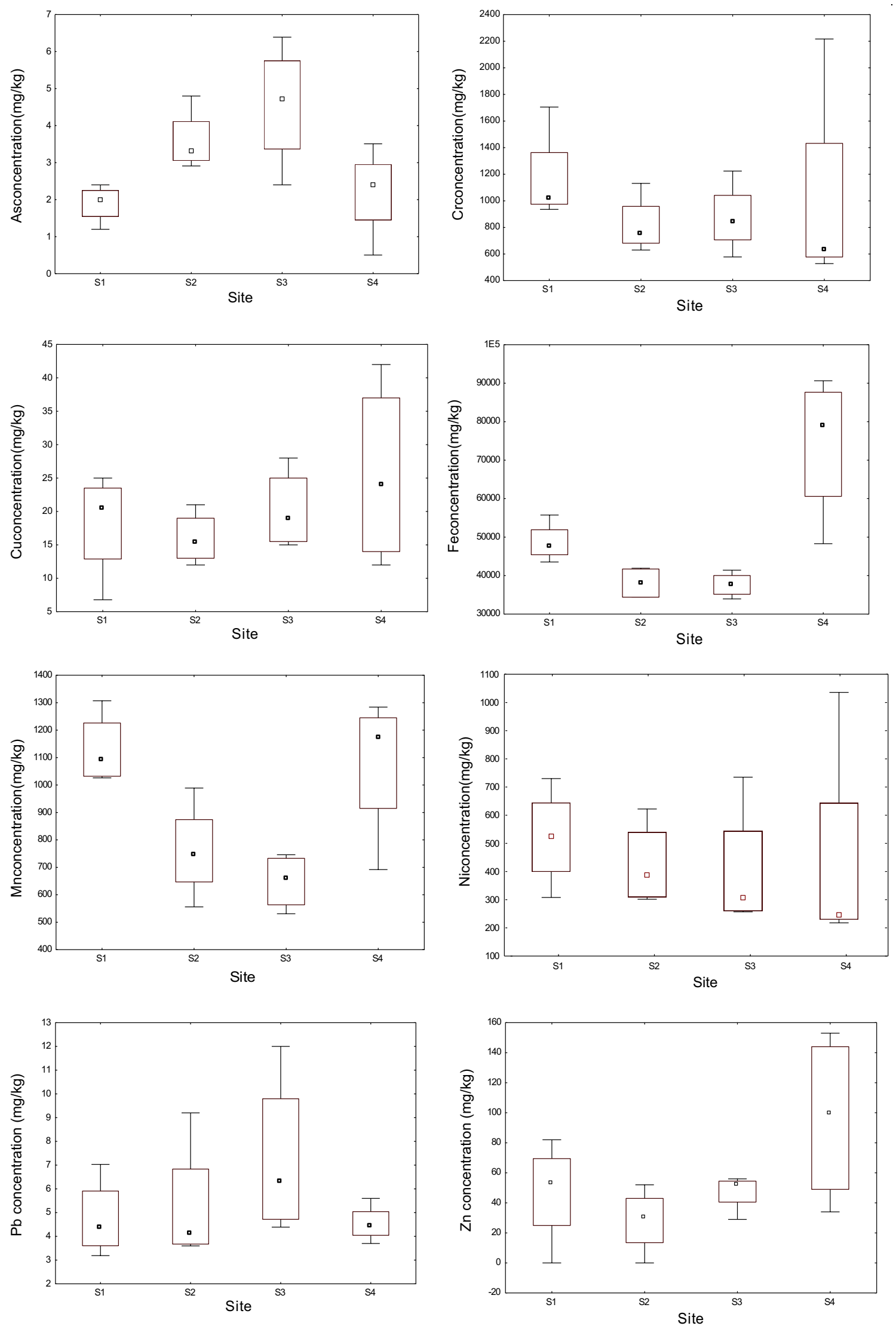

Fig. 2 Spatial distribution of concentrations values of some heavy metals in the sediments of Spekboom River. Median, 25th and 75th percentiles are shown in the box; whiskers indicate the maximum and minimum values 
Table 2 Analysis of variance (ANOVA) of metal/metalloid concentrations among sites and seasons

\begin{tabular}{|c|c|c|c|c|c|c|}
\hline \multirow[t]{2}{*}{ Heavy metals } & \multicolumn{3}{|l|}{ Sites } & \multicolumn{3}{|l|}{ Seasons } \\
\hline & MS & $\mathrm{F}$ & $p$ & MS & $\mathrm{F}$ & $\mathrm{p}$ \\
\hline As & 6.1475 & 4.6287 & 0.022570 & 2.2275 & 0.96505 & 0.440896 \\
\hline $\mathrm{Cr}$ & 96,602 & 0.42786 & 0.736706 & 380,967 & 2.46283 & 0.112604 \\
\hline $\mathrm{Cu}$ & 66.081 & 0.84968 & 0.493079 & 380,967 & 2.46283 & 0.112604 \\
\hline $\mathrm{Fe}$ & $1.173511 \mathrm{E}+09$ & 11.5877 & 0.000739 & $3.663760 \mathrm{E}+08$ & 0.52228 & 0.675053 \\
\hline $\mathrm{Mn}$ & 223,467 & 6.9122 & 0.005889 & 25,264 & 0.3085 & 0.818823 \\
\hline $\mathrm{Ni}$ & 11,005 & 0.16674 & 0.916742 & 205,769 & 11.8906 & 0.000661 \\
\hline $\mathrm{Pb}$ & 6.1442 & 1.10206 & 0.386204 & 12.9905 & 3.3623 & 0.055034 \\
\hline $\mathrm{Zn}$ & 3405.42 & 2.71682 & 0.091283 & 3117.42 & 2.35195 & 0.123658 \\
\hline
\end{tabular}

Bold values indicate $p<0.05$ geological process and the impact of human activities on heavy metal pollution (Muller 1969).

The value of the geo-accumulation index is calculated by the following equation:

$$
\mathrm{I}_{\text {geo }}=\log 2\left(\mathrm{C}_{x} / 1.5 \mathrm{~B}_{n}\right)
$$

where $C_{x}$ is the concentration of the examined metal in the sediment, $\mathrm{Bn}$ is the geochemical background value of a given metal in the shale (Turekian and Wedepohl 1961) and the factor 1.5 is used to account for the possible variations in the background values. There are seven classes of geo-accumulation index (Muller 1969). The classes range from Class 0 (unpolluted) to Class 6 (extremely polluted); $0\left(\mathrm{I}_{\text {geo }} \leq 0\right)$ uncontaminated, class $1\left(0<\mathrm{I}_{\text {geo }}<1\right)$ uncontaminated to moderately contaminated, class $2\left(1<\mathrm{I}_{\text {geo }}<2\right)$ moderately contaminated, class $3\left(2<\mathrm{I}_{\text {geo }}<3\right)$ moderately to heavily contaminated, class $4\left(3<\mathrm{I}_{\text {geo }}<4\right)$ highly contaminated, class $5\left(4<\mathrm{I}_{\text {geo }}<5\right)$ heavily to extremely contaminated, class $6\left(\mathrm{I}_{\mathrm{geo}} \geq 5\right)$ extremely contaminated (Barbieri, 2016).

\section{Results and discussion}

There were variations in the mean concentrations of the heavy metals along the river. The highest mean concentrations of As and $\mathrm{Pb}$ were recorded at Site 3, the highest concentrations of $\mathrm{Cr}, \mathrm{Cu}, \mathrm{Fe}$ and $\mathrm{Zn}$ were recorded at Site 4, and the highest mean concentration of $\mathrm{Mn}$ and $\mathrm{Ni}$ were recorded at Site 1 (Table 1 and Fig. 2). The highest mean concentrations of $\mathrm{As}, \mathrm{Cu}$ and $\mathrm{Pb}$ were at $\mathrm{S} 3$, the highest concentrations of $\mathrm{Cr}$, $\mathrm{Fe}$ and $\mathrm{Zn}$ at $\mathrm{S} 4$, and the highest concentration of $\mathrm{Mn}$ and $\mathrm{Ni}$ at $\mathrm{S} 1$. The mean concentrations of $\mathrm{Cr}$ exceeded the guideline value of $37.3 \mathrm{mg} \mathrm{kg}^{-1}$ and the average shale value of $90 \mathrm{mg} /$ $\mathrm{kg}$ also at all sites. The mean Fe concentrations exceeded the average shale value of $47,200 \mathrm{mg} / \mathrm{kg}$ at Site 1 and Site 4 . The mean concentrations of $\mathrm{Mn}$ exceeded the average shale value of $850 \mathrm{mg} / \mathrm{kg}$ at Site 1 and Site 4 . The mean concentrations of $\mathrm{Ni}$ exceeded the background values of $68 \mathrm{mg} / \mathrm{kg}$ at all the sites, and the mean $\mathrm{Zn}$ concentration exceeded the average shale value at Site 4 (Table 1). There were significant differences in the concentrations of As, Fe and Mn among the sites (Table 2).

The differences in heavy metal concentrations among the sampling sites are attributed to the different human activities. The highest mean concentrations of $\mathrm{Cr}, \mathrm{Cu}, \mathrm{Fe}$ and $\mathrm{Zn}$ were recorded at Site 4 . This site is located at the confluence of Spekboom and Steelpoort rivers. The Steelpoort River is reported to be contaminated with heavy metals from mining, agricultural and sewage effluents (Matlou et al. 2017). The highest mean concentrations of $\mathrm{Mn}$ and $\mathrm{Ni}$ were found in the sediments collected at Site 1 , which is mainly surrounded by agricultural activities.

The high concentrations of $\mathrm{Cr}, \mathrm{Mn}$ and $\mathrm{Ni}$ in the river are of concern. The sources of $\mathrm{Cr}$ in freshwater ecosystems include agricultural activities, municipal wastes, laundry chemicals, paints, leather, road run off due to tire wear, brake wires, radiators (Dixit and Tiwari, 2008). However, in this study, the main sources of $\mathrm{Cr}$ could be from the ferrochrome mining and smelting operations in the area. Studies in the Northwest Province of South Africa also reported high concentration of $\mathrm{Cr}$ (above the standard limits) in the Upper Crocodile River (Nde and Mathuthu 2018). Chromium and its salts are used in different products, such as pigments, paints, fungicides and chrome. High concentration of $\mathrm{Cr}$ can negatively affect most sensitive invertebrates ((DWAF 1996). In humans, high $\mathrm{Cr}$ concentration can cause allergic dermatitis (Scragg 2006).

Manganese is one of the most abundant trace elements in soils, where it occurs as oxides and hydroxides, and in water as small particles. The principal anthropogenic sources are industrial activities, use of fossil fuels and pesticides. Manganese compounds are used in fertilizers, varnish and fungicides and as livestock feeding supplements. In this study, the highest concentration of Mn was recorded at Site 1 and could be from the agricultural activities in the area.

Nickel occurs only at very low levels in the environment and is essential in small doses, but it can be toxic when the maximum tolerable level is exceeded. The Ni contamination

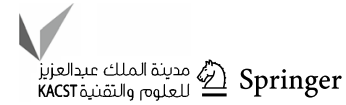



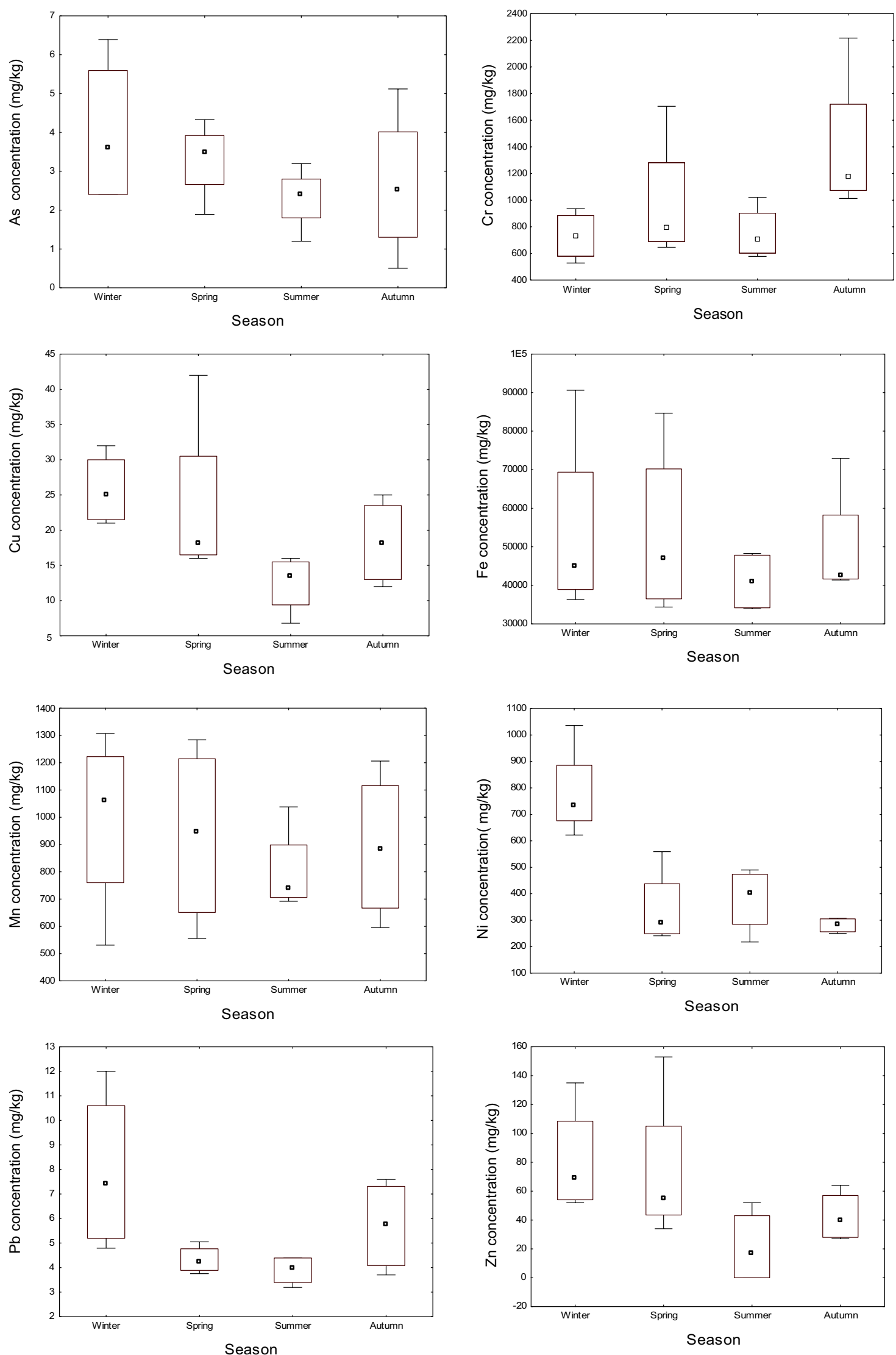

Fig. 3 Seasonal distribution of concentrations values of some heavy metals in the sediments of Spekboom River. Median, 25th and 75th percentiles are shown in the box; whiskers indicate the maximum and minimum values 


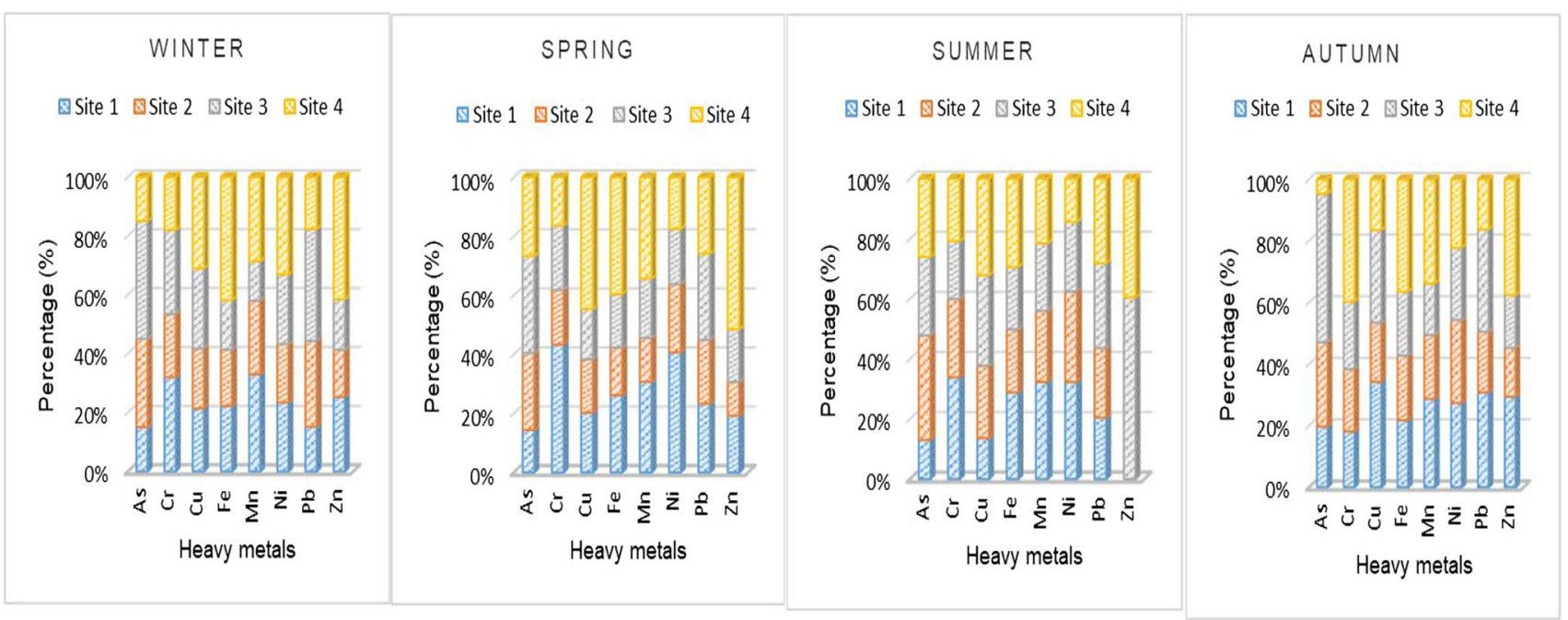

Fig. 4 The percentage (\%) distribution of heavy metals in the sediments of the Spekboom River at the different seasons

Table 3 Correlation coefficient matrix for metals in sediment samples from Spekboom River (values in bold are significant at $p<0.05)$

\begin{tabular}{|c|c|c|c|c|c|c|c|c|}
\hline Metal & As & $\mathrm{Cr}$ & $\mathrm{Cu}$ & $\mathrm{Fe}$ & Mn & $\mathrm{Ni}$ & $\mathrm{Pb}$ & $\mathrm{Zn}$ \\
\hline As & 1.000 & -0.293 & 0.405 & -0.492 & -0.553 & 0.024 & 0.612 & -0.050 \\
\hline $\mathrm{Cr}$ & & 1.000 & -0.287 & 0.138 & 0.203 & -0.171 & -0.187 & -0.159 \\
\hline $\mathrm{Cu}$ & & & 1.000 & 0.282 & 0.106 & 0.243 & 0.754 & 0.612 \\
\hline $\mathrm{Fe}$ & & & & 1.000 & 0.738 & -0.085 & -0.043 & 0.547 \\
\hline $\mathrm{Mn}$ & & & & & 1.000 & 0.103 & -0.202 & 0.553 \\
\hline $\mathrm{Ni}$ & & & & & & 1.000 & 0.233 & 0.162 \\
\hline $\mathrm{Pb}$ & & & & & & & 1.000 & 0.322 \\
\hline $\mathrm{Zn}$ & & & & & & & & 1.000 \\
\hline
\end{tabular}

Table 4 Enrichment factor for heavy metal in sediments in the Spekboom River (Highlighted values indicate enrichment)

\begin{tabular}{lllll}
\hline Heavy metals & Site 1 & Site 2 & Site 3 & Site 4 \\
\hline $\mathrm{As}$ & 0.14 & 0.34 & 0.44 & 0.10 \\
$\mathrm{Cr}$ & $\mathbf{1 2 . 5 9}$ & $\mathbf{1 1 . 3 0}$ & $\mathbf{1 2 . 1 9}$ & $\mathbf{9 . 3 8}$ \\
$\mathrm{Cu}$ & 0.39 & 0.44 & 0.57 & 0.32 \\
$\mathrm{Fe}$ & 1 & 1 & 1 & 1 \\
$\mathrm{Mn}$ & $\mathbf{1 . 2 9}$ & $\mathbf{1 . 1 1}$ & 0.96 & 0.71 \\
$\mathrm{Ni}$ & $\mathbf{7 . 4 4}$ & $\mathbf{7 . 7 5}$ & $\mathbf{7 . 4 2}$ & $\mathbf{3 . 6 0}$ \\
$\mathrm{Pb}$ & 0.23 & 0.33 & 0.46 & 0.13 \\
$\mathrm{Zn}$ & 0.48 & 0.37 & 0.63 & 0.57 \\
\hline
\end{tabular}

in the river is of great concern as it can cause health problems, such as cardiovascular diseases, chest pain, dizziness, dry cough, headache, kidney diseases and nausea in humans (Fashola et al. 2016). Some chemical fertilizers and pesticides are known to contain $\mathrm{Ni}$ (Rajmohan and Elango, 2005). In addition, the source of higher Ni concentration at the downstream sites might be from urban and industrial effluents (Li 2014) and combustion of fossil fuels (Pulles et al. 2012).

Seasonally, the highest mean heavy metal concentrations were recorded in winter, except for $\mathrm{Cr}$ and $\mathrm{Fe}$ where the highest mean concentrations were recorded in autumn and spring, respectively (Fig. 3). The lowest mean concentrations
Table 5 Geo-accumulation index for heavy metal in sediment of the Spekboom River (values in bold indicate contamination)

\begin{tabular}{lllllllll}
\hline Site & $\mathrm{As}$ & $\mathrm{Cr}$ & $\mathrm{Cu}$ & $\mathrm{Fe}$ & $\mathrm{Mn}$ & $\mathrm{Ni}$ & $\mathrm{Pb}$ & $\mathrm{Zn}$ \\
\hline $\mathrm{S} 1$ & -3.361 & $\mathbf{3 . 1 1 4}$ & -1.891 & -0.540 & -0.176 & $\mathbf{2 . 3 5 5}$ & -2.653 & -1.591 \\
$\mathrm{~S} 2$ & -2.444 & $\mathbf{2 . 6 0 2}$ & -2.077 & -0.897 & -0.742 & $\mathbf{2 . 0 5 7}$ & -2.515 & -2.336 \\
$\mathrm{~S} 3$ & -2.096 & $\mathbf{2 . 6 9 4}$ & -1.737 & -0.913 & -0.977 & $\mathbf{1 . 9 7 8}$ & -2.047 & -1.586 \\
$\mathrm{~S} 4$ & -3.145 & $\mathbf{3 . 4 7 8}$ & -1.404 & -0.249 & -0.240 & $\mathbf{2 . 0 9 7}$ & -2.727 & -0.563 \\
\hline
\end{tabular}


of all the metals were recorded in summer except $\mathrm{Ni}$, with the lowest recorded in autumn. Higher concentrations As, $\mathrm{Cr}, \mathrm{Fe}$ and $\mathrm{Mn}$ found during winter might be due to the low water flow in winter which resulted in the precipitation of these metals in the sediments than the other seasons (Islam et al. 2015). The seasonal distribution pattern of heavy metals obtained revealed variation of heavy metals in the different sites of the river (Fig. 4).

The pattern of the correlation coefficient shows strong associations of the following metals in the sediments, $\mathrm{As}-\mathrm{Pb}$, $\mathrm{Cu}-\mathrm{Pb}, \mathrm{Pb}-\mathrm{Zn}, \mathrm{Cu}-\mathrm{Zn}, \mathrm{Fe}-\mathrm{Zn}$ and $\mathrm{Mn}-\mathrm{Zn}$ (Table 3). Based on the correlation coefficients, Fe showed a strong significant positive correlation with $\mathrm{Mn}(\mathrm{r}=0.738 ; \mathrm{p}<0.05)$, As showed a strong significant positive correlation with $\mathrm{Pb}$ $(r=0.612 ; p<0.05)$, and $\mathrm{Zn}$ showed strong significant positive correlations with $\mathrm{Cu}, \mathrm{Fe}$ and $\mathrm{Mn}(r=0.612,0.547$ and 0.553 , respectively; $p<0.05$ ). These strong relationships among the metals suggest that the metals originated from similar pollution sources as well as similar geochemical characteristics Suresh et al. (2012) and Wang et al. (2015). There was a strong negative correlation between As and $\mathrm{Mn}$ $(r=0.553)$, an indication that they differ in origin and the absence of a correlation among the metals suggests that they are not controlled by a single factor (Sojka et al 2019).

\section{Enrichment factor and geo-accumulation index}

The enrichment factor (EF) was applied to assess the possible sources of the metals. The results of the $\mathrm{EF}$ are shown in Table 4; As (0.10-0.44), $\mathrm{Cr}$ (9.38-12.59), $\mathrm{Cu}(0.32-0.57)$, $\mathrm{Mn}$ (0.71-1.29), Ni (3.60-7.75), Pb (0.13-0.46) and $\mathrm{Zn}$ (0.37-0.57). The EF values of $\mathrm{As}, \mathrm{Cu}, \mathrm{Mn}, \mathrm{Pb}$ and $\mathrm{Zn}$ were all below 2, thus these heavy metals show deficiency to minimal enrichment in the sediments. The EF value of $\mathrm{Cr}$ was between 5 and 20 at all the sites and indicate a significant enrichment in the sediments. The EF value of Ni was between 2 and 5 at Site 4 (deficiency to minimal enrichment) and EF values were between 5 and 20 at Sites 1, 2 and 3 (significant enrichment). The relatively higher EF values of $\mathrm{Cr}$ and $\mathrm{Ni}$ may be due to human activities occurring in the catchment (Duncan et al. 2018). However, the relatively low EF values of Mn despite the high mean concentrations recorded is an indication that it originates mainly from natural sources (Sojka et al. 2019).

Geo-accumulation index; the calculated $\mathrm{I}_{\text {geo }}$ values based on the average shale are presented in Table 5 . The $\mathrm{I}_{\mathrm{geo}}$ values for $\mathrm{As}, \mathrm{Cu}, \mathrm{Fe}, \mathrm{Mn}, \mathrm{Pb}$ and $\mathrm{Zn}$ were below 1 and fall in class ' 0 ', indicating background concentration in all the sites. The $I_{\text {geo }}$ value of Cr falls in class 3 at Site 2 and Site 3, indicating moderately to heavily contaminated, and $\mathrm{Cr}$ falls in class 4 at Site 1 and Site 4, indicating highly contaminated. Nickel falls in class 2 at Site 3 and class 3 at Site 1, 2 and 4, indicating moderately to heavily contaminated sediments. The high $\mathrm{I}_{\text {geo }}$ values of $\mathrm{Cr}$ and $\mathrm{Ni}$ showed that these sites received a considerable amount of $\mathrm{Cr}$ and $\mathrm{Ni}$ contamination (Bing et al. 2019). The high levels of $\mathrm{Cr}$ may be due to unregulated chrome mining activities occurring in the catchment (Islam et al. 2015).

\section{Conclusion}

The concentrations of heavy metals of the Steelpoort River shows that the river sediments are highly contaminated with $\mathrm{Cr}$ and $\mathrm{Ni}$ but not the other metals and highlights the effect of various anthropogenic activities on the river. The concentrations of $\mathrm{Cr}$ and $\mathrm{Ni}$ at all the sites were higher than the average shale values, while the concentrations of $\mathrm{Fe}$ and $\mathrm{Mn}$ were higher than the average shale values at Site 1 and Site 4. Based on the enrichment factor and geo-accumulation index, the sediments are significantly enriched by $\mathrm{Cr}$ and $\mathrm{Ni}$ and minimal to no enrichment by the other heavy metals. The enrichment of $\mathrm{Cr}$ and $\mathrm{Ni}$ in the sediments is caused by human activities such as mining, agriculture and WWTP. The spatial distributions of heavy metals in the sediment have identified the sites that are vulnerable and are under threat with specific heavy metals. The contaminated sediments could act as secondary sources of heavy metal pollution to the water body. Some of the heavy metal concentrations have already exceeded the guideline values and there is a need for urgent measures to reduce the level of pollution to avoid negative impact on the aquatic biota and humans.

Supplementary Information The online version contains supplementary material available at https://doi.org/10.1007/s13201-021-01464-8.

Acknowledgements The author is grateful to the postgraduate students of the Water Laboratory in the Department of biodiversity for their valuable contributions during the field work.

Funding The research was supported financially by the Flemish InterUniversity Council (VLIR-UOS), Belgium.

\section{Declarations}

Conflicts of interest The author declares no conflicts of interest.

Open Access This article is licensed under a Creative Commons Attribution 4.0 International License, which permits use, sharing, adaptation, distribution and reproduction in any medium or format, as long as you give appropriate credit to the original author(s) and the source, provide a link to the Creative Commons licence, and indicate if changes were made. The images or other third party material in this article are included in the article's Creative Commons licence, unless indicated otherwise in a credit line to the material. If material is not included in the article's Creative Commons licence and your intended use is not permitted by statutory regulation or exceeds the permitted use, you will need to obtain permission directly from the copyright holder. To view a copy of this licence, visit http://creativecommons.org/licenses/by/4.0/. 


\section{References}

Addo-Bediako A (2020) Assessment of heavy metal pollution in the blyde and steelpoort rivers of the Olifants river system. South Africa Pol J Environ Stud 29(5):3023-3039

Addo-Bediako A, Marr S, Jooste A, Luus-Powell WJ (2014) Are metals in the muscle tissue of Mozambique tilapia a threat to human health? A Case Study of Two Impoundments in the Olifants River, Limpopo, South Africa. Ann Limnol - Int J Lim 50:201-210

Arnason JG, Fletcher BA (2003) A 40+ year record of Cd, Hg, Pb, and $\mathrm{U}$ deposition in sediments of Patroon Reservoir, Albany County, NY, USA. Environ Pollut 123:383-391

Barbieri M (2016) The importance of enrichment factor (EF) and geoaccumulation index $\left(\mathrm{I}_{\mathrm{geo}}\right)$ to evaluate the soil contamination. $\mathrm{J}$ Geol Geophys 5:237

Benzer S (2017) Concentrations of arsenic and boron in water, sediment and the tissues of fish in emet stream (Turkey). B Environ Contam Tox 98:805-810

Bervoets L, Blust R (2003) Metal concentrations in water, sediment and gudgeon (Gobio gobio) from a pollution gradient: relationship with fish condition factor. Environ Pollut 26:9-19

Bhuiyan MAH, Parvez L, Islam MA, Dampare SB, Suzuki S (2010) Heavy metal pollution of coal mine-affected agricultural soils in the northern part of Bangladesh. J Hazard Mater 173:384-392

Bing H, Wu Y, Zhou J, Sun H, Wang X, Zhu H (2019) Spatial variation of heavy metal contamination in the riparian sediments after two-year flow regulation in the Three Gorges Reservoir, China. Sci Total Environ 649:1004-1016

Brady JP, Ayoko GA, Martens WN, Goonetilleke A (2014) Enrichment, distribution and sources of heavy metals in the sediments of Deception Bay, Queensland. Australia Mar Pollut Bull 81(1):248-255

CCME (Canadian Council of Ministers of the Environment) (2012) Environmental Quality Guidelines: Water quality guidelines and sediment quality guidelines for the protection of aquatic life. In Canadian Council of Ministers of the Environment

Deely JM, Fergusson JE (1994) Heavy metal and organic matter concentrations and distributions in dated sediments of a small estuary adjacent to a small urban area. Sci Total Environ 153:97-111

Dixit S, Tiwari S (2008) Impact assessment of heavy metal pollution of Shahpura Lake, Bhopal. India Int J Environ Res 2(1):37-42

Du Plessis A (2017) Global water quality challenges. In: du Plessis A (ed) Freshwater challenges of South Africa and its upper Vaal River: current state and outlook. Springer Nature, Switzerland

Duncan AE, De Vries N, Nyarko KB (2018) Assessment of heavy metal pollution in the sediments of the river Pra and its tributaries. Water Air Soil Pollut 229:272

DWAF (Department of Water Affairs and Forestry) (1996) South African Water Quality Guidelines: Volume 7: Aquatic Ecosystems, Second Edition. Pretoria, South Africa

Fashola M, Ngole-Jeme V, Babalola O (2016) Heavy metal pollution from gold mines: environmental effects and bacterial strategies for resistance. Int J Environ Res Public Health 13(11):1047

Gao XL, Chen C-TA (2012) Heavy metal pollution status in surface sediments of the coastal Bohai Bay. Water Res 46:1901-1911

Gao C, Lin Q, Bao K, Zhao H, Zhang Z, Xing W, Wang G (2014) Historical variation and recent ecological risk of heavy metals in wetland sediments along Wusuli River, Northeast China. Environ Earth Sci 72:4345-4355

Hanif N, Eqani SAMAS, Ali SM, Katsoyiannis IA, Tanveer ZI, Bokhari H (2016) Geo-accumulation and enrichment of trace metals in sediments and their associated risks in the Chenab River, Pakistan. J Geochem Explor 165:62-70
Hook SE, Gallagher EP, Batley GE (2016) The role of biomarkers in the assessment of aquatic ecosystem health. Integr Environ Assess Manag 10:327-341

Islam MS, Ahmed MK, Raknuzzaman M, Habibullah-Al-Mamun M, Islam MK (2015) Heavy metal pollution in surface water and sediment: a preliminary assessment of an urban river in a developing country. Ecol Indic 48:282-291

Jan AT, Azam M, Siddiqui K, Ali A, Choi I, Haq QMR (2015) Heavy metals and human health: mechanistic insight into toxicity and counter defense system of antioxidants. Int J Mol Sci $16: 29592-29630$

Li J (2014) Risk assessment of heavy metals in surface sediments from the Yanghe River, China. Int J Environ Res Public Health 11:12441-12453

Matlou K, Addo-Bediako A, Jooste A (2017) Benthic macroinvertebrate assemblage along a pollution gradient in the steelpoort River, Olifants river system. Afr Entomol 25:445-453

Muller G (1969) Index of geo-accumulation in sediments of the Rhine river. GeoJournal 2:108-118

Nde SC, Mathuthu M (2018) Assessment of potentially toxic elements as non-point sources of contamination in the upper crocodile catchment area, north-west province, South Africa. Int J Environ Res Public Health 15:576

Pulles T, Van Der Gon HD, Appelman W, Verheul M (2012) Emission factors for heavy metals from diesel and petrol used in European vehicles. Atmos Environ 61:641-651

Rajmohan N, Elango L (2005) Distribution of iron, manganese, zinc and atrazine in groundwater in parts of palar and Cheyyar river basins, South India. Environ Monit Assess 107:115-131

Scragg A (2006) Environmental biotechnology. Oxford University Press, Oxford

Sojka M, Jaskuta J, Siepak M (2019) Heavy metals in bottom sediments of reservoirs in the lowland area of Western Poland: concentrations, distribution. Sour Ecol Risk Water 11:56

Suresh G, Sutharsan P, Ramasamy V, Venkatachalapathy R (2012) Assessment of spatial distribution and potential ecological risk of the heavy metals in relation to granulometric contents of Veeranam lake sediments, India. Ecotoxicol Environ Saf 84:117-124

Turekian KK, Wedepohl KH (1961) Distribution of the elements in some major units of the earth's crust. Geol Soc Am Bull 72:175-192

UNEP(DEC)/MED (2005) Methods for sediment sampling and Analysis. WG.282/Inf.5/ Rev.1. UNEP

Van Veelen M, Dhemba N (2011) Water Quality Report. Report No. PWMA04/B50/00/8310/7. Department of Water Affairs, Pretoria, South Africa

Wang Y, Yang L, Kong L, Liu E, Wang L, Zhu J (2015) Spatial distribution, ecological risk assessment and source identification for heavy metals in surface sediments from Dongping Lake, Shandong, East China. CATENA 125:200-205

Yang Y, Zhou Z, Bai Y, Cai Y, Chen W (2016) Risk Assessment of Heavy Metal Pollution in Sediments of the Fenghe River by the Fuzzy Synthetic Evaluation Model and Multivariate Statistical Methods. Pedosphere 26:326-334

Zhang X, Li Z, Takeuchi N, Wang F, Wang S, You X, Zhou P (2017) Heavy metal-polluted aerosols collected at a rural site. Northwest China J Earth Sci 28:535-544

Publisher's Note Springer Nature remains neutral with regard to jurisdictional claims in published maps and institutional affiliations. 